\title{
Vote with Your Rabbi: The Electoral Effects of Religious Institutions in Israel *
}

\author{
Michael Freedman, University of Haifa
}

Accepted at Electoral Studies

\begin{abstract}
How do religious parties mobilize local support and what impact does different political strategies have on neighborhoods? Previous literature focuses on the social welfare benefits distributed by religious parties. In this paper, I analyze how religious political parties in Israel generate grassroots support among voters by allying with Jewish religious institutions. Using original data, I examine the association between the timing of entry of religious institutions into neighborhoods and local voting patterns for Israeli national elections. I find that religious institutions are associated with a 4-percentage point increase in the local vote share for religious parties, where this effect is larger for religious institutions with connections to political parties. My results suggest that the primary mechanism driving these results are that these institutions influence the vote choice of existing residents by distributing tangible goods. In contrast, changes to the composition of the neighborhood through in-migration has a more limited effect on voting patterns. These findings highlight the impact of religious institutions on the social and political fabric of local communities.
\end{abstract}

*I thank Fotini Christia, Rich Nielsen, and Guy Grossman for their guidance and comments on this paper. I also received valuable comments from Avi Ebenstein, Noam Gidron, Gershon Shafir, Nadav Shelef, Amy Erica Smith, Chagai Weiss, and Thomas Zeitzoff. I also benefited from feedback received during sessions at the MPSA 2017 conference, APSA 2017 conference, and POMEPS 2018 conference. I received financial support for the project from the Israel Institute and ASMEA. 
Prominent examples of religious party success include the Muslim Brotherhood in Egypt, the AKP in Turkey, and the Ennadhda Party in Tunisia (Grewal et al., 2019). Many observers believe that electoral gains by religious groups have had tumultuous consequences, with citizens increasingly divided over the role of religion in politics and society. This raises the following question: what factors explain the success of religious political parties in the Middle East?

Scholars typically attribute the political success of religious parties to two related factors. First, a rich literature points to the role of social welfare provision in securing the support of voters (Davis and Robinson, 2012; Cammett, 2014). According to this rationale, people vote for religious parties, even if they are ideologically distant from the ideas of the religious parties, since they value the material goods provided by religious actors. Another related explanation notes that people support religious political parties due to their reputation for good governance (Cammett and Luong, 2014). Building off the former literature on social provision, which commonly examines the direct link between parties and voters, I focus on the mediating role of local religious institutions (between parties and voters) in helping religious parties achieve electoral success.

To assess this, I examine the role of religious institutions in Israeli politics, organizations that have successfully linked religious parties in Israel with voters at the grassroots level. While these religious institutions primarily provide educational and religious services, I argue that these religious institutions also fulfill an important political role in Israel. Like the Christian religious right in the United States who formed an alliance with the Republican party (Schlozman, 2015; Whitehead and Perry, 2020), Jewish religious institutions have chosen to form powerful alliances with Israel's religious political parties. In this political arrangement, leaders of important religious institutions receive government resources and enjoy a very privileged status, highly influencing Israeli politics via their control over many party decisions (Liebman, 1993; Willis, 1995; Bick, 2007; Davis and Robinson, 2012). 
I theorize that the relationship between religious political parties and religious institutions resembles clientelism since there is an exchange of goods and services for political support. ${ }^{1}$ Specifically, religious political parties ensure that religious institutions receive funding from the state. In turn, religious institutions provide legitimacy to these parties. At the local level, they also encourage residents to vote for religious political parties by providing club goods that are largely subsidized by state funding.

To test this hypothesis, I spatially link all available data on local voting for national elections (held between 1977-2015) with data on the founding of over 3,000 religious institutions. For my main results, I use a difference in differences design that exploits the plausibly exogenous timing of entry of such organizations into neighborhoods.

I find that religious institutions have a significant impact on people's political behavior, increasing support on average for religious political parties in local neighborhoods by approximately four percentage points in national elections. At the same time, I also find that areas with additional religious institutions experience less support for centrist parties. As elections are very close in Israel's parliamentary system involving many political parties, these votes potentially make the difference between a narrow right-wing government that relies exclusively on right-wing and religious parties (such as Netanyahu's 2015-2018 government coalition), versus a broader government that builds on the support of some center or left-wing parties (such as Netanyahu's 2013-2015 government coalition).

To understand what is driving these results, I distinguish between two channels. First, that existing residents change their vote choice due to mobilization efforts by religious institutions, where residents support religious parties in exchange for tangible benefits. Second, that the results are driven by selective migration, where the entry of religious institutions into neighborhoods is followed by the out-migration of non-religious residents and the in1 While there is some disagreement among scholars what exactly constitutes clientelism, I use the definition given by Stokes (2007): "the term clientelism can be defined as giving material goods in return for electoral support, where the criterion of distribution that the patron uses is simply: did you/will you support me?". 
migration of religious migrants. I find more support for the first channel, where the political effects are largest for religious institutions that are connected to political parties. Using census data on immigration, I also find that religious institutions do not appear to be associated with short term changes to the composition of the neighborhood population.

This paper makes three key contributions. First, it adds to the literature on the political role of religious institutions. Many scholars note that religious institutions will contribute to social capital, community building, and political participation (Smidt, 2003; Harrigan and El-Said, 2009; Grzymala-Busse, 2012; Gerber, Gruber and Hungerman, 2016). In contrast, my results suggest that by allying with partisan political parties, religious institutions contribute to the local strengthening of sectarian religious parties. Second, the study makes a contribution to the field of comparative electoral studies. While most studies focus on the direct relationship between parties and voters, this study focuses on the novel mediating role of religious institutions in Israeli politics. Third, it provides a novel methodological approach to estimating the political impact of religious organizations on local politics by exploiting differences in the timing of entry of new religious institutions into neighborhoods. Moreover, the empirical framework developed in this paper can also be used for the study of other types of organizations with ties to electoral actors, such as welfare organizations or NGOs.

\section{Theory of Religious Influence on Politics}

Churches and religious movements have historically played a large role in politics. Evangelical Christian movements have been linked with the democratization of South America, and churches were responsible for the party formation of Europe (Kalyvas, 1996; Warner, 2000; Freston, 2008; Smith, 2019). Indeed, a clean "separation of church and state" no longer describes the politics of the vast majority of democratic countries (Fox, 2008). This is especially

marked in the Middle East, where Islamist parties enjoy electoral advantages (Cammett and Maclean, 2014; Grewal et al., 2019). 
In turn, scholars have investigated the relationship between religious parties and religious institutions (Wald, Silverman and Fridy, 2005; Freston, 2008; Grzymala-Busse, 2012). One point of agreement in the literature is that people's religious values and social identity are highly shaped by their local religious community (Djupe and Calfano, 2013; Woolfalk, 2013; McClendon and Riedl, 2015; Margolis, 2018). This suggests an important role for local religious institutions.

Drawing on research on clientelism and ethnic politics, I propose a general framework of local political influence that incorporates political parties, religious institutions, and local communities. In this framework, religious institutions enter partisan relationships with other political parties. Through this exchange, religious institutions help deliver votes and political support from their local religious communities. In turn, political parties grant political access and material resources to religious institutions.

This framework implies that religious institutions can generate political support in a way that resembles clientelistic practices in developing democracies (Scott, 1972; Chandra, 2007; Blaydes, 2010; Hicken, 2011). ${ }^{2}$ Thus, by providing religious, educational, and material goods to the population, religious institutions fulfill a role that is analogous to brokers in a clientelistic system where voters who receive benefits are encouraged to vote for a religious political party (Stokes et al., 2013).

Adopting this theoretical framework, it is apparent that religious institutions are well positioned to act as brokers and coordinate between political parties and voters. First, they enjoy high levels of legitimacy in their local community. This gives them access to information that allows them to identify core supporters and potential swing voters in their community (Kitschelt and Wilkinson, 2007). Second, religious institutions are well positioned to distribute party resources within local communities, as club goods can be morally justified 2 This comparison may seem surprising since many scholars assume that the benefits of religious affiliation are usually non-material in nature (Iannaccone, 1998). Yet, churches also provide tangible material benefits such as charity, education, welfare services, and social networks which can aid in finding employment (Berman, 2000; Iyer, 2016). 
by norms which dictate that community members come first (Iannaccone, 1998; Berman, 2000). Third, religious institutions help mitigate the monitoring problems associated with vote choice in any clientelistic arrangement. Daily contact with members and norms of reciprocity within the community help ensure that voters do not renege and vote for other political parties during elections (Finan and Schechter, 2012).

However, it is important to note that this framework only resembles clientelism since there is no direct vote buying on a large-scale. Moreover, the reward or punishment that individuals receive from parties or brokers is less contingent on actual vote choice, which is usually unknown due to the secrecy of the vote ballot. At the same time there are conceptual similarities, as voters are persuaded by religious institutions to vote for certain parties, with the expectation that greater political representation will translate into future material gain through larger budgets and subsidies to religious communities.

At the same time, there is actual potential for backlash to religious institutions. First, if the benefits of religious institutions are directed only to members of the religious group, this may be perceived by non-religious residents as discriminatory, or even as a form of political corruption. Second, it is likely that new religious institutions make religion more of a salient issue in the community (Wald, Silverman and Fridy, 2005). This may make religion more of a cleavage issue, leading to political polarization and higher support for political parties with a non-religious ideology.

In the next section, I describe how this theoretical framework can be applied to religious institutions in the Israeli context.

\section{Religious Parties and Religious Institutions in Israel}

In Israel, the three major religious political parties (The Jewish Home, Shas, and United Torah Judaism) receive on average about 20 percent of the combined current vote in Israel. In Israel's Proportional Representation (PR) electoral system, this electoral strength has 
historically given the religious political parties a large impact on national politics (Liebman, 1993). However, there has been little work on religious institutions, the intermediaries who are critical for connecting these religious parties with voters.

In Israel, religious institutions are composed of religious study groups known as Yeshivot and Jewish faith organizations. Yeshivot are religious schools that are led by charismatic and influential religious leaders. Their intense focus on Jewish studies makes them comparable to other religious schools such as Madrasas or seminaries (Heilman, 1996). While the model of the Yeshiva has ancient roots in Judaism and was primarily found in the Ashkenazi Haredi world, the institution has also become prominent among the Sephardic Haredi and Religious Zionist communities (Don-Yehiya, 1994). ${ }^{3}$ According to Israel's Central Bureau of Statistics, there are currently over 140,000 Yeshiva students in Israel, divided among 1,600 governmentfunded institutions. ${ }^{4}$ Virtually all students are males over the age of 18 , with very few Yeshivot designated for women. In addition to Yeshivot, Jewish faith organizations have been set up across the country to provide religious services, whose purpose is to proselytize and bring Israelis closer to religious observance.

The majority of religious institutions have formed important links to religious political parties. Specifically, religious institutions fulfill an important brokerage role in Israel where they help deliver votes to partisan political parties in exchange for political access and material resources. In this exchange, religious political parties (the patron) ensure that religious institutions (the client) receive state resources. In turn, the religious institutions attract political support for the client by ensuring that the local population who benefits from these services (the voters) support the religious parties.

Religious institutions can influence who voters support via different channels. In this context, it is important to distinguish between services that religious institutions provide to 3 Yeshivot are generally organized by religious affiliation, gender, and marital status. See the appendix for more details.

4 To put this number in perspective, about 300,000 students study in colleges and universities in Israel. 
their students, versus services that are provided to the local community (Cammett and Issar, 2010). Students typically receive a rich religious education, a monthly stipend, access to material goods and free loans from affiliated institutions such as Gemachim, and a partial or full exemption from military service (Shetreet, 1999). Potential services that religious institutions provide to the community include free religious lectures, volunteer services, charity handouts, and social welfare services.

Naturally, religious institutions vary in important ways that may impact their political impact. Specifically, they differ in their religious ideology, engagement with the state, and political affiliation. Moreover, while the vast majority of religious institutions are UltraOrthodox institutions, an influential minority identify with the Religious Zionist community (such as Hesder Yeshivot). In addition, religious institutions vary in the extent that they focus exclusively on their students versus a broader engagement that includes providing services to the community. Typically, religious institutions affiliated with Shas or the Religious Zionist community provide more services to the greater community. In contrast, Ultra-Orthodox institutions are more insular with services more targeted to their members. Another important factor is whether religious institutions receive government funding and form political connections with specific religious parties.

Accounts on religious institutions in Israel are divided over their impact on politics and society. For instance, several scholars have described how religious institutions successfully use material resources to influence people's political behavior. Davis and Robinson (2012) describe how Shas was able to attract new voters in Israel via a combination of providing social welfare and its allied network of religious institutions. This was accomplished primarily through their alliance with Rabbi Ovadiah Yosef and the El Hama'ayan educational network. These institutions accomplished two goals: "strengthening" local Jewish religious identity and increasing support for religious parties from voters who had voted for non-religious political parties in the past. Similarly, Shetreet (1999) argues that all the religious parties funnel 
resources through the religious institutions to get religious individuals to vote for religious parties and attract new voters through proselytizing activities. These accounts suggest that providing educational, religious, and welfare services to the greater community can help religious institutions attract voters to religious political parties.

In contrast, other accounts note a strong backlash to religious institutions. As noted by Enos and Gidron (2016), there are major tensions between secular and Ultra-Orthodox Jews in Israel. Due to the high birthrate of Ultra-Orthodox Jews, there is a fear among secular Jews that they will become a minority (Efron, 2003). These tensions are especially present at the neighborhood level, particularly in mixed neighborhoods where the character of the neighborhood is contested. Local tensions tend to focus on two related issues. First, public resources such as schools are allocated along religious observance lines. Under these circumstances, decisions regarding which group will receive a public resource can be highly contentious. Second, 'culture wars' over religious issues such as the public observance of the Sabbath or gender segregation can become local flash-points.

Several organizations have even been set up to counter local Ultra-Orthodox influence, including groups such as The Secular Forum or Be Free Israel. These organizations use campaigns that are similar in spirit to NIMBY campaigns against immigrants (Hopkins, 2010), where residents are encouraged to organize to prevent the entry and influence of religious groups. Local media also contains many anecdotes of these religious clashes. Recent flashpoints include fights in Arad over controversial religious posters (Ben Zikri, 2017), religious boycotts over 'immodest' malls in Jerusalem (Hasson, 2013), and protests over allocating buildings for religious kindergartens (Sharon, 2013). In the media, hadata (opposition to religious indoctrination, primarily in the school curriculum) has become a widely used term (Peled and Peled, 2018). ${ }^{5}$ Overall, this implies that religious institutions may activate and mobilize political identities across both religious and counter-religious lines.

5 The Secular Forum even has a testimonials page where citizens are encouraged to report instances of hadata in schools. See: http://www.hiloni.org.il/testimonials 


\section{Data}

To study the effects of these religious institutions on voting, I created an original panel dataset of geolocated religious institutions and fine-grained election returns. I used data on the percentage of the vote that went to each political party at the census tract for elections held between 1977-2015. With this data, I measured the proportion of the vote that went to religious parties, center parties, and left-wing parties in national elections for each census tract over time. I spatially merged the electoral data with data on over 3,000 geo-located religious institutions.

My electoral data came from two different sources. Data for elections held between 20062015 was acquired from Israel's elections office. For elections held between 1977-2003, I acquired data from the Israel Social Sciences Data Center. Since I was interested in the local impact of religious institutions, I used the lowest unit of analysis: census tracts. ${ }^{6}$

According to the CBS methodology report, small localities less than 10,000 residents are treated as one census tract. When a locality is more than 10,000 residents, it is divided into census tracts where each area is on average 3,000- 4,000 residents, roughly corresponding to neighborhoods in large cities. These tracts are divided in a way that tries to preserve the homogeneity of the unit, where land use, historical factors, and demographic factors are considered.

It is also important to note that the boundaries of some of the census tracts change between censuses for administrative reasons and due to population growth. This means that there was a need to merge data between elections released under different census tract mappings. For instance, for elections held between 1996 and 2009, election data was released at the 1995 census tract level. However, the elections data prior to 1996 was released at the 1983 census tract level. To overcome this challenge, I merged the data using the 1995 units,

6 During the time period I am interested in, Israel carried out 3 national censuses (1983, 1995, 2008). When Israel administers a census, it divides localities into geographic units of different sizes (quarter, sub-quarter, census tracts). 
using a conversion key of the census tracts of 1983 and 1995, available in the GeographicalStatistical Division of Urban Localities in Israel (hard copy). Similarly, I merged the 2013 and 2015 election data based on the 2008 census tracts, using a conversion key of the census tracts of 2008 and 1995 that was acquired from Israel's Central Bureau of Statistics.

My data on religious institutions was webscraped from the NGO database maintained by Guidestar in Israel. ${ }^{7}$ Their database maintains a list of all nonprofit organizations in Israel (over 41,000). Critically, this data also includes information on the date an institution was established, a precise address, type of institution, and a brief description of its objectives and activities. Each nonprofit in Israel is categorized by their area of activity and there are over 80 unique categories, including categories for Yeshivot and Jewish faith organizations. Thus, I was able to identify all registered institutions in Israel. According to Figure A2, religious institutions represent approximately 16 percent of all institutions in Israel.

I merged religious institutions to census tracts using QGIS, where census tracts were polygons and religious institutions were points. The 1995 shape file of census tracts was acquired from Israel's Central Bureau of Statistics. Latitude and longitude points for religious institutions were calculated by inputting the address of the religious institutions into Google Maps API (using a Python script).

To identify religious institutions with political connections, I acquired data on government funding from the Public Knowledge Workshop (Hasadna), including all support given to NGOs between 2006-2015. ${ }^{8}$ Institutions that received any support over the period were defined as politically connected religious institutions. Finally, I identified Religious Zionist and Sephardic organizations using a keyword search of their name or organization objectives. ${ }^{9}$

7 For the English website, see http://www.guidestar.org.il/GS_Index?lang=en_US

8 This Israeli organization promotes government transparency and citizen involvement in politics by collecting data on government spending and proposed legislation.

9 I identified Religious Zionist institutions using the following 6 keywords: Rav Kook (spiritual founder of Religious Zionism), Yeshivot Hesder (Yeshivot associated with the Religious Zionist movement who combine learning with army service), Torah-Based group (Garin Torani, groups of Religious Zionists who engage in community projects), Religious Zionism 
Finally, it is important to note several limitations to the data. First, Israel's laws relating to NGOs were passed in 1981. Thus, according to Guidestar, in the early 1980s many institutions that were recognized as NGOs were not 'new', but older organizations which were registered under Ottoman Law. However, this should not affect the main results which rely on NGOs founded in the 1990s and 2000s. Second, my data records the founding date and original address of the organization. This implies that additional branches or offices that may have been added are not included in the data and neither is information on religious institutions that move, although this seems unlikely in an organization's early years. Furthermore, some institutions registered with addresses whose location Google Maps was unable to identify with certainty. This was mostly a problem for older organizations, as street names may have changed in the interim in some communities. Overall, these types of measurement error are expected to attenuate the results and bias the results downwards.

\section{Descriptive Statistics}

In Figure 1, I plot the yearly number of new religious institutions over time in Israel. The figure suggests that there has been a steady growth in the number of religious institutions in Israel, with 100-200 new institutions created each year. ${ }^{10}$ The growth in religious institutions, including those that target the 'born again' (Ba'alei Teshuva), is also likely connected to the resurgence of religion in Israel (Ben-Porat, 2013). For example, the 2009 Social Survey indicates that 21 percent of the Jewish population report becoming more religious during (Tzionut Hadatit), Bnei Akiva (Religious Zionist youth group), and National Religious (Dati Leumi, alternative Hebrew term for Religious Zionism). I identified Sephardic institutions using the following 5 keywords: Sephard, Groups from the East (Edot Hamizrach, common term for Mizrachi or Sephardi Jews), Porat Yosef (a leading Sephardic Yeshiva in Jerusalem), Yemen (Teiman, a term for Yemenite Jews), and Yosef Chaim (a famous Sephardi rabbi from Iraq).

${ }^{10}$ Israel's registration laws passed in 1981 help explain why there was a small number of 'new' institutions in 1981 as organizations were slow to register, and the very large number in 1983 as older and newer organizations registered. 
their lifetime, compared to 14 percent who report becoming less religious. ${ }^{11}$ In addition, five percent of the Jewish population define themselves as 'newly religious', with nearly half of these respondents attributing the change in their level of religious observance to the influence of family or environment.

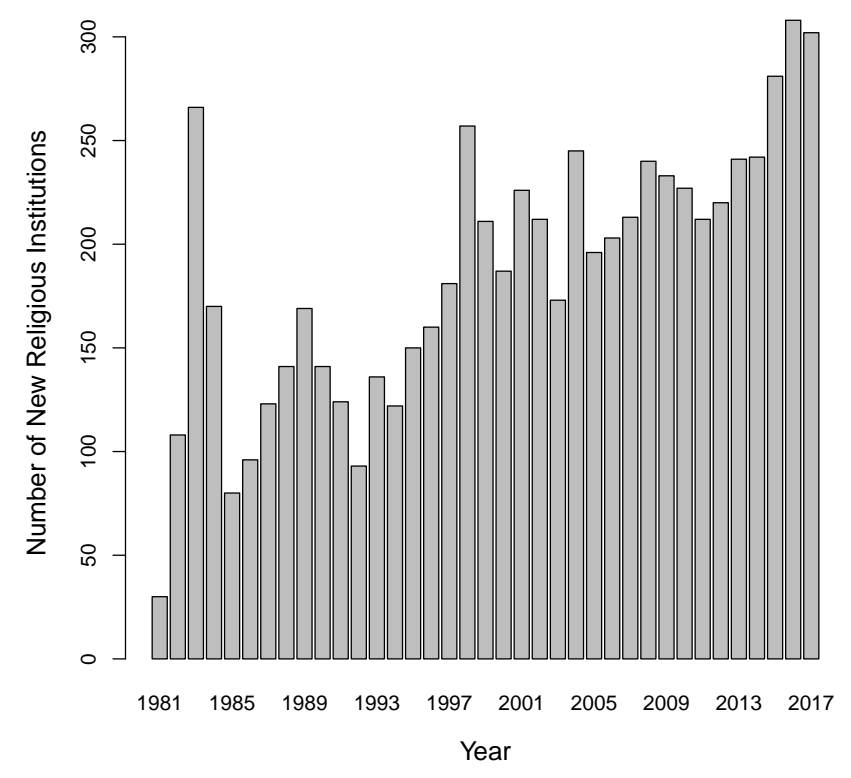

Figure 1: New Religious Institutions in Israel

In Figure 2, I plot the total budget that religious institutions in Israel received from the Ministry of Education. ${ }^{12}$ The figure indicates that the overall budget for religious institutions has ranged in the past ten years between half a billion to slightly more than one billion Israeli Shekels. Notably, the budget is significantly lower in years where some religious parties were excluded from the governing coalition (such as the 2013 government with the anti-clerical party Yesh Atid), and much higher when all the religious parties were part of the governing ${ }^{11}$ This representative survey was published by Israel's Central Bureau of Statistics. In 2009, the survey focus was on family life and religiosity. For a summary of the results, see http: //www.cbs.gov.il/statistical/seker-chevrati-e124.pdf

${ }^{12}$ In Figure A1, I plot the total amount of government funding for individual religious institutions. While the majority of state funding comes from the Ministry of Education, some institutions also receive money from the Ministry of Welfare or the Ministry of Defense. 


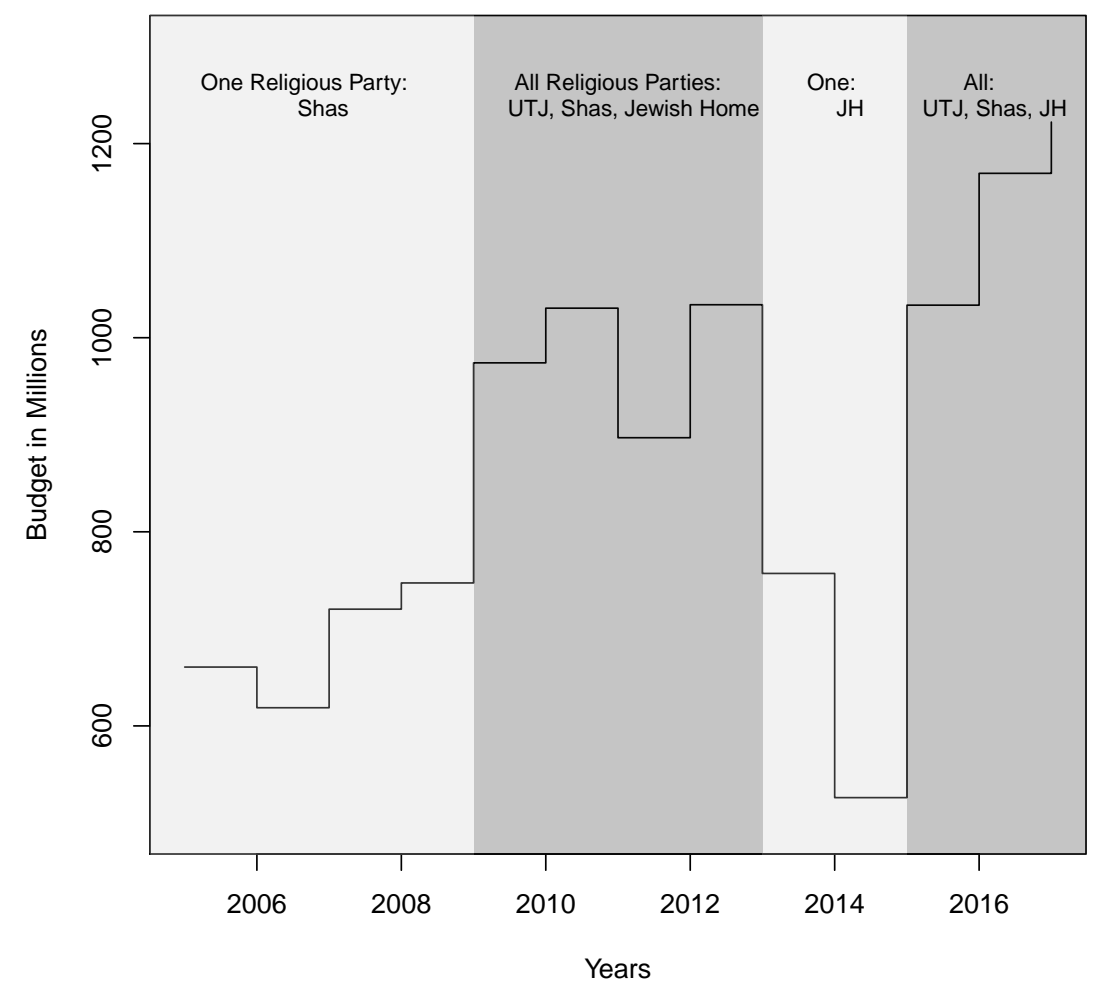

Figure 2: Religious Parties and the Educational Budget for Religious Institutions The figure shows the overall yearly budget in Israeli Shekels (millions) allocated by the Ministry of Education to religious institutions.

coalition (the 2015 government which includes all three religious parties). ${ }^{13}$ This underscores the importance which many religious institutions place on having religious political parties join the government coalition, as the majority of Yeshivot have historically received state funding, which in many instances comprises more than half of their overall funding. ${ }^{14}$

${ }^{13}$ The overall budget for religious institutions is set by the government. Detailed guidelines (in Hebrew) describe eligibility and how each institution receives money according to a set formula determined by the type of religious institution, number of students, and citizenship of the students (see http://cms . education.gov.il/EducationCMS/Units/MT/ MivchanimLetmicha/MibhaneyTmiha.htm)

${ }^{14}$ Based on a perusal of financial documents which I collected and analyzed, which religious institutions are obligated to file annually. Other important sources of funding are donations, made primarily by foreign donors. 


\section{Empirical Strategy}

My empirical strategy is motivated by the observation that where to geographically establish a new religious institution is not made randomly by its founders. Many religious institutions are typically set up in neighborhoods that are becoming more religious or where the share of the religious population is growing. Alternatively, religious institutions are set up in places where the founders believe there is potential to succeed. Thus, regular OLS estimates that do not consider these factors would be biased. ${ }^{15}$

To help overcome this identification problem, I adopt a difference in differences strategy. This strategy compares places which received religious institutions in the 1990s with places which received religious institutions between 2000 and 2015. This identification strategy assumes that places that received religious institutions are similar in kind and that the timing when a religious institution enters a neighborhood is largely exogenous. This assumption seems plausible as setting up new institutions depends on the availability of land, public buildings, and access to resources. How long these steps take varies greatly with the slow regulatory process in Israel.

I propose the following model to estimate the effect that religious institutions have on local voting choice:

$$
\operatorname{Vot}_{\mathrm{j}, \mathrm{t}}=\mu_{j, t}+\gamma \cdot \mathrm{D}+\delta \cdot \mathrm{T}+\alpha \cdot(\mathrm{D} \cdot \mathrm{T})+\mathrm{X}^{\prime} \beta+\varepsilon
$$

where the outcome variable $V o t_{j, t}$ is the proportion of people who voted for a religious party in census tract $j$ and elections $t$. $D$ takes on a value of 1 for treated units which received religious institutions in the $90 \mathrm{~s}$, while $D$ takes on a value of 0 for control units which received religious institutions between 2000 and 2015. T takes on a value of 1 for the post-treatment

${ }^{15}$ If religious institutions are built in neighborhoods with highly homogeneous religious populations, this could bias the results downwards since new institutions would likely have little effect on the already high proportion of individuals who support religious parties. 
period (after 1990) and a value of 0 in the pre-treatment period (before 1990). The model includes important census-level covariates such as number of synagogues and number of eligible voters. Note that the quantity of interest is $\alpha$, which identifies the effect of having religious institutions on voting rates among treated units after 1990. Standard errors are clustered by census tract.

To check the parallel trends assumption for the difference in differences design, Figure 3 plots the over-time trends in vote share for religious parties, disaggregated by when neighborhoods initially received a religious institution. As indicated by the figure, one can identify four distinct groups: neighborhoods that received religious institutions for the first time in the 1980s or earlier (mostly homogeneous religious areas making it a biased treatment group), neighborhoods that received religious institutions for the first time in the 1990s (treated), neighborhoods that received religious institutions for the first time in the 2000s (control), and neighborhoods that never received a religious institution (biased control). The figure shows that the vote share for religious parties in neighborhoods that received religious institutions in the 1990s (treated) or 2000s (control) were very similar for elections held between 1977-1988, which provides support for the parallel trends assumption for these two groups. Therefore, my analysis focuses on these two groups, while excluding the very religious neighborhoods (biased treatment group) and areas that are not receptive to having religious institutions (never received).

In Table 1, I assess to what extent the treatment and control groups are comparable based on demographic characteristics associated with the religious population in Israel. The results indicate that these groups are similar on average in their pre-1990's voting behavior, and for demographic covariates (from the 1983 census) that are associated with religious populations such as household size, share of youth in the population, and ethnic background.

Finally, to get a better sense of the neighborhoods used for the analysis, I plot in Figure 4 maps of the treatment and control neighborhoods for select cities: Jerusalem, Tel Aviv, Haifa, 


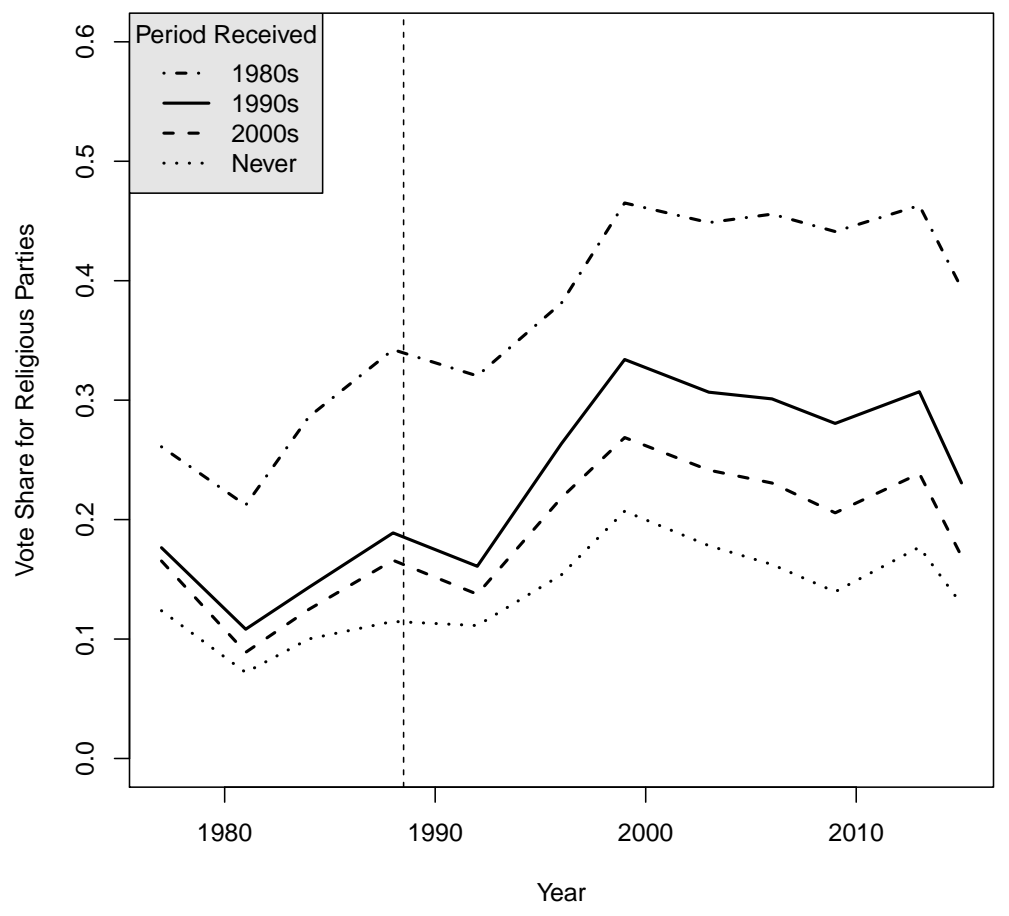

Figure 3: Group Voting Trends Over Time, by Initial Exposure to Religious Institutions Treated units were first exposed to religious institutions during elections held between the 1988 and 1999 elections (1990s). Control units were first exposed to religious institutions during elections held between the 1999 and 2015 elections (2000s). 
Table 1: Comparison of Groups for Difference in Differences Analysis

\begin{tabular}{lccc}
\hline \hline Covariate & Control & Treated & P-values \\
\hline Vote Share for Religious Parties (1977-1998) & 0.14 & 0.15 & 0.01 \\
Vote Share for Likud (1977-1998) & 0.39 & 0.38 & 0.24 \\
Vote Participation (1977-1998) & 0.78 & 0.78 & 0.22 \\
Persons in Household (1983) & 3.30 & 3.36 & 0.38 \\
Proportion Ages 0-19 (1983) & 0.11 & 0.11 & 0.69 \\
Proportion born in Asia-Africa (1983) & 0.69 & 0.67 & 0.58 \\
\hline
\end{tabular}

Notes: Average measures for demographic covariates are taken from Israel's 1983 census.

and Beer Sheva. Figure 4a indicates that Jerusalem, a city with a large Ultra-Orthodox population, has the largest number of relevant neighborhoods, with religious institutions moving to Ramot (North Jerusalem) and the southern parts of the city during the 1990s and 2000s. In addition, Figure 4 shows that religious institutions were founded during this period in secular cities such as Tel Aviv and Haifa, unexpected places for religious institutions. The maps also indicate that the control and treated neighborhoods are in close geographic proximity within cities, indicating that the neighborhoods are comparable. ${ }^{16}$

\section{Main Results}

I present the results for my main specifications using a difference in differences design in Table 2 (see Equation 1). Note that the analysis only considers census tracts which received their first religious institution in the 1990s (between the 1988 and 1999 elections) or the 2000s (between the 1999 and 2015 elections). The results from Table 2 indicate that places with 16 This is consistent with research which finds that new immigrants tend to move to neighborhoods that are adjacent to existing immigrant enclaves (Saiz and Wachter, 2011). 


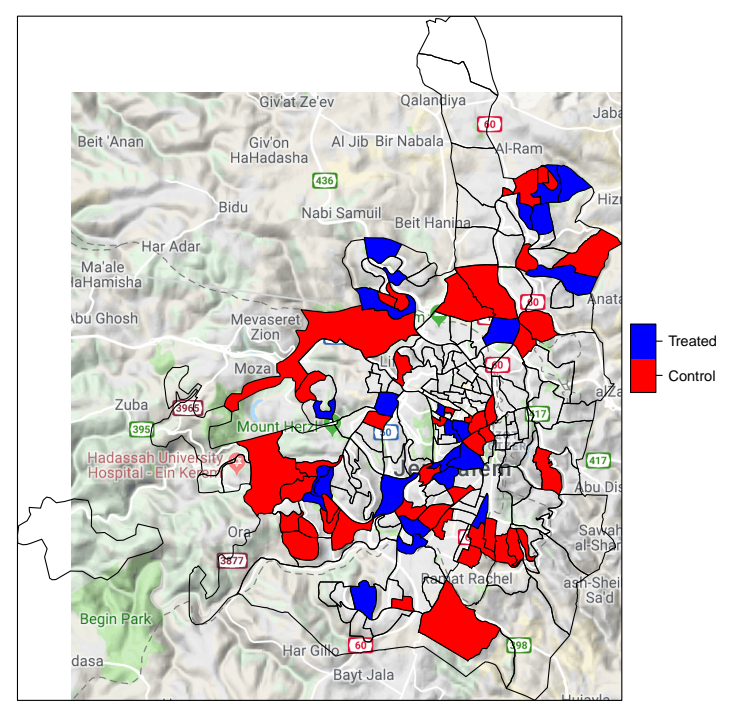

(a) Jerusalem

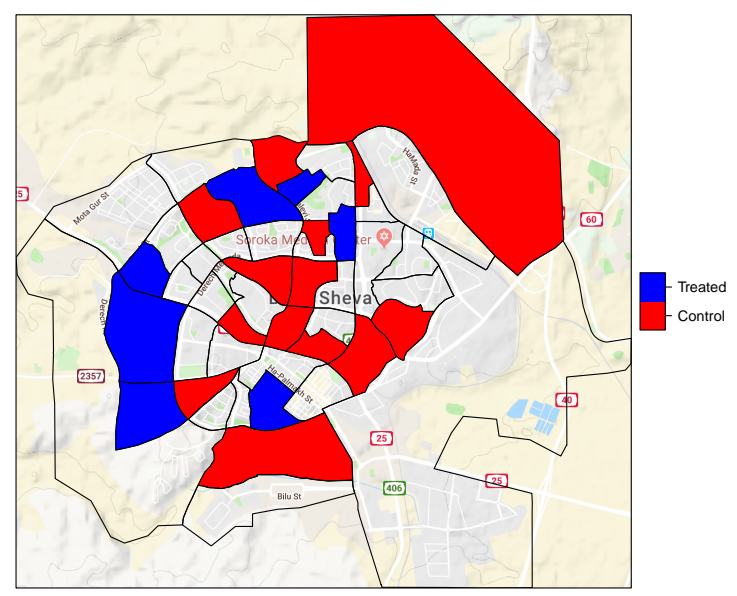

(c) Beer Sheva

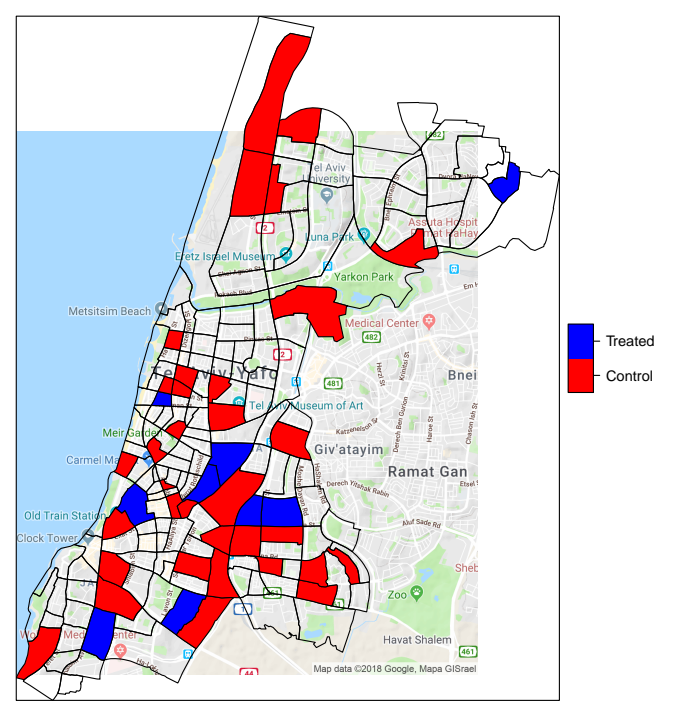

(b) Tel Aviv-Jaffa

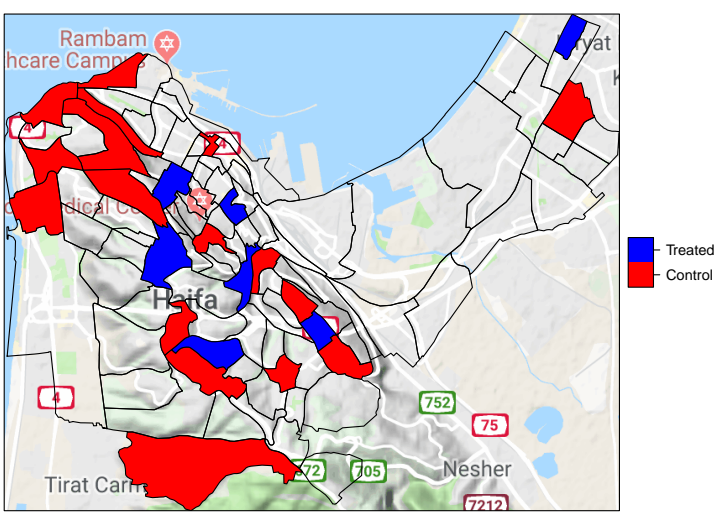

(d) Haifa

Figure 4: Location of Religious Institutions, Treated and Control Units in Select Cities The plot shows 1995 census tracts, shaded blue for treated units and red for control units. 
new religious institutions in the 90 s increased their vote proportion for religious parties by four percentage points on average for future elections (these results are also seen graphically in Figure 3). The effect is both statistically significant and substantively large. The results imply that religious institutions increase the vote share for religious parties by approximately 20 percent (baseline mean of 0.20 ). This effect is comparable to the effect of terror attacks in Israel, where studies indicate that support for right-wing parties increases between one to six percentage points after terror attacks (Berrebi and Klor, 2008).

Table 2: Impact of Religious Institutions on Voting for Religious Parties, DID

\begin{tabular}{lcc}
\hline & $\begin{array}{c}\text { Dependent Variable: Vote for Religious Parties } \\
\text { Model 1 }\end{array}$ & Model 2 \\
\hline Religious Institutions in the 90s & 0.018 & $0.020^{*}$ \\
& $(0.013)$ & $(0.012)$ \\
Post 1990s & $0.078^{* * *}$ & $0.074^{* * *}$ \\
& $(0.005)$ & $(0.005)$ \\
Synagogues & & $0.057^{* * *}$ \\
& & $(0.004)$ \\
Eligible Voters (1000s) & & $-0.016^{* * *}$ \\
Treatment X Post & $0.042^{* * *}$ & $0.002)$ \\
& $(0.014)$ & $(0.012)$ \\
Constant & $0.136^{* * *}$ & $0.166^{* * *}$ \\
& $(0.007)$ & $(0.009)$ \\
\hline Dependent Variable Mean & 0.20 & 0.20 \\
Observations & 7,051 & 7,051 \\
Adj. R-squared & 0.067 & 0.132 \\
\hline
\end{tabular}
${ }^{* * *} \mathrm{p}<.01 ;{ }^{* *} \mathrm{p}<.05 ;{ }^{*} \mathrm{p}<.1$

Notes: Standard errors are clustered by census tract.

In Figure 5, I assess the impact of religious institutions on support for all types of parties for elections held between 1984-2015. In each specification, the dependent variable is a specific political party and the explanatory variable is voting patterns in treated areas. The results suggest that the increase in support for religious parties is mainly due to an increase in 


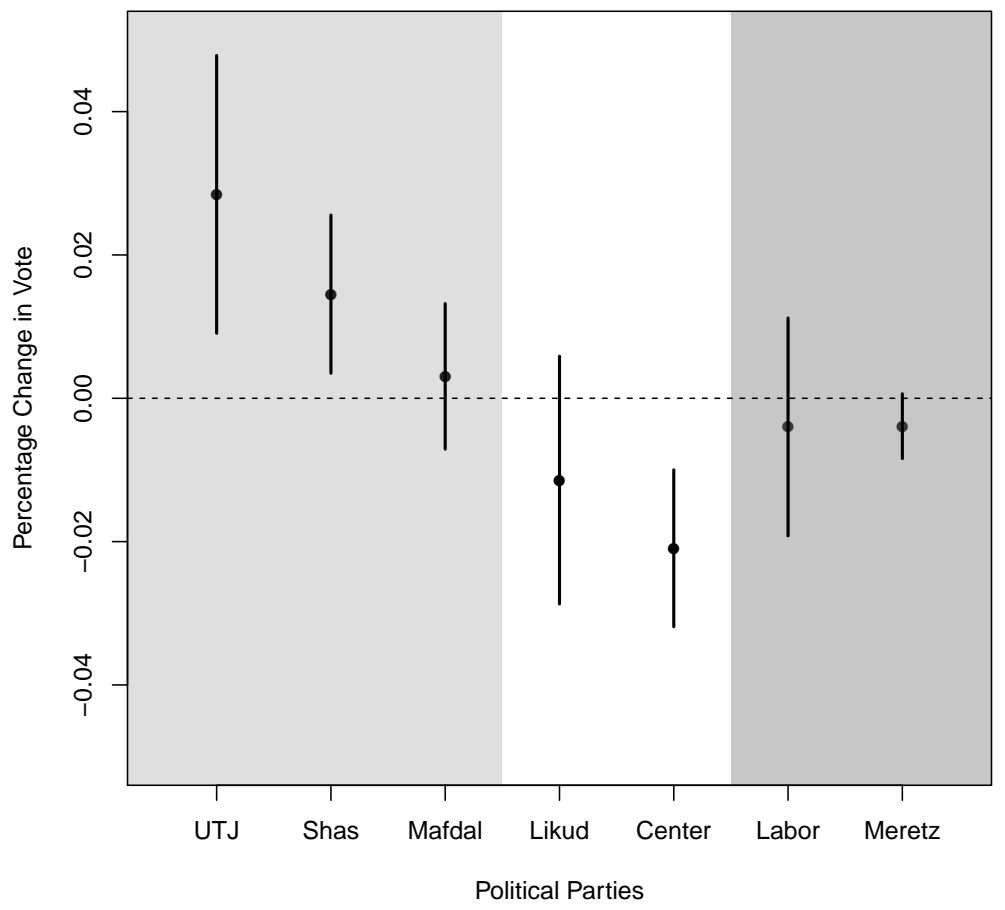

Figure 5: Impact of Religious Institutions on Voting, Disaggregated by Party See Table 2 notes. This plot shows the coefficients and 95 percent confidence intervals of the change in party vote share for treated units post the 1990s. Due to data limitations, each regression only analyzes data from the 1984 elections and onwards.

support for the Ultra-Orthodox parties (United Torah Judaism and Shas). Interestingly, the results also suggest a large decrease in support for centrist (Kadima/Shinui) and right-wing parties (Likud). In combination, these results suggest that religious institutions have taken votes at the expense of the mainstream right/center political parties. In contrast, the figure suggests that religious institutions are associated with only marginal changes in support for left-wing parties (Labor and Meretz), providing evidence that religious institutions are not generating electoral backlash.

To increase the confidence in the results, I present several robustness checks in the appendix. First, I show that the results are not driven by highly religious cities. In these cities, some of the expansion of religious institutions into other areas may be driven by the natural 
growth of the religious population. Thus, I rerun the difference in differences design from Equation 1 after excluding Jerusalem and Bnei Brak from the sample. Table A1 indicates that religious institutions had a significant impact (3.4 percentage points) on local voting patterns, even in cities with smaller religious populations. Second, I show the results are robust to other specifications. The results in Table A2 (Model 2) from a two-way fixed-effects specification indicate that an increase between elections in the number of new religious institutions increases the vote proportion for religious parties by 1-2 percentage points on average. In columns 3 and 4 , I use linear and quadratic time trends. These specifications help account for time-varying unobserved confounders, such as the percentage of the religious population in a given area. The estimates are significant. However, the smaller effect size (2.5 percentage points) suggests that the individual effects of religious institutions are smaller than their cumulative impact. Third, I show that the results are robust to other measurement choices. Table A3 indicates that the results are robust to using a dummy measure for new religious institutions.

\section{Types of Religious Institutions and Potential Mechanisms}

Why is the entry of religious institutions associated with effects on local vote choice? In this section, I examine different channels that could help explain the findings.

Specifically, I explore to what extent there is heterogeneity across different types of religious institutions. I consider two types of institutions: religious institutions who are connected to political parties that receive state funding, and religious institutions who rely on donors and receive no state support. In Table 3, I compare the effects of these different types

of religious institutions using a two-way fixed-effects specification for each type of religious institution separately. The results suggest that the effect of politically-connected religious institutions on voting is nearly double (0.019) than the effects for religious institutions without political connections (0.011). Overall, these results suggest that religious institutions with 
political connections can have a larger influence on local voting patterns by having more resources to distribute to the local community. This result is also consistent with literature that finds that voters are likely to strategically give their vote to parties in exchange for tangible benefits (Stokes, 2007).

Table 3: Impact of Different Religious Institutions on Voting for Religious Parties

\begin{tabular}{|c|c|c|}
\hline & $\begin{array}{l}\text { Dependent Variable: } \\
\text { Model } 1\end{array}$ & $\begin{array}{l}\text { Vote for Religious Parties } \\
\quad \text { Model } 2\end{array}$ \\
\hline Funded Religious Institutions & $\begin{array}{c}0.019^{*} \\
(0.011)\end{array}$ & \\
\hline Non-Funded Religious Institutions & & $\begin{array}{c}0.011^{* * *} \\
(0.003)\end{array}$ \\
\hline Synagogues & $\begin{array}{l}0.008^{* *} \\
(0.003)\end{array}$ & $\begin{array}{c}0.010^{* * *} \\
(0.004)\end{array}$ \\
\hline Eligible Voters (1000s) & $\begin{array}{l}-0.001 \\
(0.001)\end{array}$ & $\begin{array}{c}-0.002^{* *} \\
(0.001)\end{array}$ \\
\hline Dependent Variable Mean & 0.20 & 0.20 \\
\hline Statistical Area FEs & Yes & Yes \\
\hline Election FEs & Yes & Yes \\
\hline Observations & 7,051 & 7,051 \\
\hline Adj. R-squared & 0.846 & 0.847 \\
\hline
\end{tabular}

\section{Alternative Explanations}

In this section I consider several alternative explanations for the results.

I have argued that religious institutions are able to influence local voting patterns by distributing resources. However, an alternative explanation would be that when a religious institution enters a neighborhood, it could initiate changes to the composition of the neighborhood. Specifically, residential preferences towards religion could lead to a geographic chain effect where people who are attracted to the new religious institute move into the neighbor- 
hood, whereas people who don't want to live in the proximity of religious institutions move out of the neighborhood (Schelling, 1971; Emerson, Chai and Yancey, 2001).

To assess this explanation, I first examined general migration patterns using Israeli census data from 2008 which asks people whether they have moved from their census tract in the last five years. Table A4 suggests that on average, 80 percent of people have not moved from their census tract, 10 percent of people have moved within the city, and 10 percent of people have moved from a different city. This indicates that the population composition of most neighborhoods is relatively steady over time. The data also suggests that migration is not more common for cities with large religious populations such as Jerusalem or Bnei Brak, compared to other cities with smaller religious populations such as Tel Aviv or Haifa.

To examine this issue further, I acquired data from Israel's Central Bureau of Statistics on internal migration and other types of population growth. The Bureau has only produced these statistics for the years 2011, and 2013-2016, allowing me to assess the short-term impact of religious institutions on immigration and other population trends for a small period of my sample. The data distinguishes between migration within cities (switching neighborhoods) and migration between cities. The results in Table 4 suggest that new religious institutions are not associated with yearly changes to immigration patterns (in-migration and out-migration) for neighborhoods. While not conclusive, these results provide some indication that migration is not the primary mechanism driving the results. ${ }^{17}$

Another explanation for the different electoral effects for religious institutions is that they are driven by heterogeneity in political affiliation among religious institutions. This seems plausible since the decision to accept government funding is related to religious ideology, where religious institutions associated with Religious Zionism or Shas being more likely to pursue government funding. The results in Figure 6 suggest that religious ideology does ${ }^{17}$ At the same time, these results cannot rule out the possibility that some religious institutions, especially large Yeshivot led by important leaders, may cause occasional long-term changes to the composition of the population within neighborhoods (Cahaner, 2012). 
Table 4: Impact of Religious Institutions on Immigration Patterns

\begin{tabular}{lcccc}
\hline & \multicolumn{2}{c}{ Migration Within Cities } & \multicolumn{2}{c}{ External Migration } \\
& Model 1 & Model 2 & Model 3 & Model 4 \\
\hline Religious Institutions & 2.660 & 1.102 & -3.765 & -0.525 \\
& $(2.351)$ & $(1.494)$ & $(2.392)$ & $(1.642)$ \\
Statistical Area FEs & Yes & Yes & Yes & Yes \\
Observations & 8,777 & 8,777 & 9,079 & 9,110 \\
Adj. R-squared & 0.812 & 0.853 & 0.740 & 0.828 \\
\hline${ }^{* * *} \mathrm{p}<.01 ;{ }^{* *} \mathrm{p}<.05 ;{ }^{*} \mathrm{p}<.1$ & & & \\
Notes: Standard errors are clustered by census tract. & &
\end{tabular}

not seem to be the main driver. For instance, religious institutions affiliated with the Religious Zionist movement have largely insignificant effects on vote choice. Similarly, Sephardic institutions affiliated with Shas seem to have little electoral effects, as well.

However, there are two important caveats to these results. First, many important Religious Zionist institutions are in the West Bank and are excluded from the analysis due to data limitations (voting data in unavailable for the West Bank). Second, many Sephardic Yeshivot have a weak affiliation with Shas, with many religious leaders maintaining broader ties with Ashkenazi Haredi institutions.

\section{Conclusion}

Religious political parties continue to flourish in many political systems. However, there is little agreement among scholars regarding how religious parties attract voters, and what impact different tactics by religious political parties have on society. In this paper, I examine the critical role that religious institutions play in Israeli politics, linking voters with religious parties. Employing a design that exploited the timing in the entry of new religious institutions into neighborhoods, I showed that religious institutions have an important influence on local politics in Israel, pushing the electorate towards religious and non-centrist parties. In the 


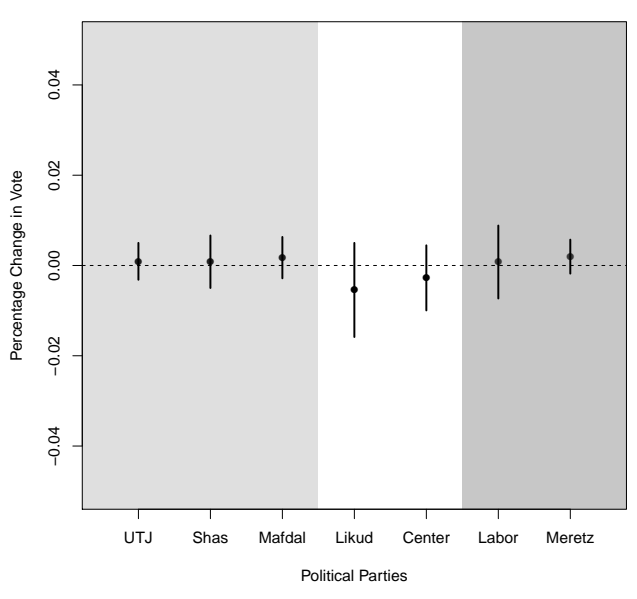

(a) Religious Zionist Institutions

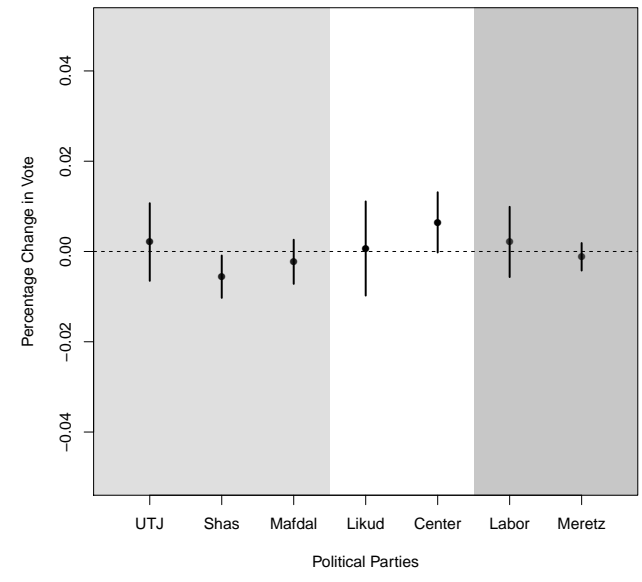

(b) Sephardic Institutions

Figure 6: Impact of Different Types of Religious Institutions on Voting, Disaggregated by Party See Table 3 notes. The plots show the coefficients and 95 percent confidence intervals of the change in party vote share using a two-way fixed effects specification. Each sub-figure shows the results for a different type of religious institution. Due to data limitations, each regression only analyzes data from the 1984 elections and onwards.

long term, clientelistic strategies have increased religious political power in Israel, but have also contributed to making the role of religion in society a core cleavage issue.

This paper makes several important contributions. First, it contributes to previous literature on religion and politics by showing conceptual similarities between clientelism and religious patronage strategies. This suggests that tactics which work effectively for secular parties can be adapted for religious ends as well. Second, this paper provides a detailed analysis on the political role of religious institutions. It suggests that in a context where religious institutions have a strong political affiliation, it is unlikely that they will have community strengthening effects.

Finally, key limitations to the study should be noted and exploited as avenues for future research. While my paper focuses on one channel of political influence for religious institutions (local impact via new institutions), this should not imply that religious institutions do not have additional political or social impacts on society. There are many ways in which religious 
institutions influence society, and my paper focuses on one understudied aspect which lends itself to causal identification. Thus, future studies can examine the social impact of religious institutions by examining other outcomes such as local cooperation or social capital. As well, one can study the broader political impacts of religious leaders by examining how they engage with and influence other political and social elites. 


\section{References}

Ben-Porat, Guy. 2013. Between state and synagogue: The secularization of contemporary Israel. Cambridge University Press.

Ben Zikri, Almog. 2017. "Clashes erupt between ultra-Orthodox and secular demonstrators in southern Israel." Haaretz. September 10. Accessed February 26, 2018. https://www.haaretz.com/israel-news/clashes-erupt-between-ultra-orthodoxand-secular-protesters-in-arad-1.5449590.

Berman, Eli. 2000. "Sect, subsidy, and sacrifice: an economist's view of ultra-orthodox Jews." The Quarterly Journal of Economics 115(3):905-953.

Berrebi, Claude and Esteban F. Klor. 2008. "Are Voters Sensitive to Terrorism? Direct Evidence from the Israeli Electorate." American Political Science Review 102(03):279-301.

Bick, Etta. 2007. "A Clash of Authority : Lay Leaders and Rabbis in the National Religious Party." Israel Affairs 13(2):401-417.

Blaydes, Lisa. 2010. Elections and Distributive Politics in Mubarak's Egypt. Cambridge University Press.

Cahaner, Lee. 2012. "Expansion processes of the Jewish Ultra-Orthodox population in Haifa." Horizons in Geography 79/80:70-87.

Cammett, Melani. 2014. Compassionate communalism: Welfare and sectarianism in Lebanon. Cornell University Press.

Cammett, Melani and Lauren M. Maclean. 2014. The Politics of Non-state Social Welfare. Cornell University Press.

Cammett, Melani and Pauline Jones Luong. 2014. "Is There an Islamist Political Advantage?" Annual Review of Political Science 17(1):187-206. 
Cammett, Melani and Sukriti Issar. 2010. "Bricks and Mortar Clientelism: Sectarianism and the Logics of Welfare Allocation in Lebanon." World Politics 62(03):381-421.

Chandra, Kanchan. 2007. Why ethnic parties succeed: Patronage and ethnic head counts in India. Cambridge University Press.

Davis, Nancy J. and Robert V. Robinson. 2012. Claiming Society for God: Religious Movements 86 Social Welfare. Indiana University Press.

Djupe, Paul A. and Brian R. Calfano. 2013. "Religious Value Priming, Threat, and Political Tolerance." Political Research Quarterly 66(4):768-780.

Don-Yehiya, Eliezer. 1994. "The book and the sword: The nationalist yeshivot and political radicalism in Israel." Accounting for fundamentalism: The dynamic character of Movements pp. 264-302.

Efron, Noah J. 2003. Real Jews : secular versus ultra-Orthodox and the struggle for Jewish identity in Israel. Basic Books (AZ).

Emerson, Michael O., Karen J. Chai and George Yancey. 2001. "Does Race Matter in Residential Segregation? Exploring the Preferences of White Americans." American Sociological Review 66(6):922-935.

Enos, Ryan D. and Noam Gidron. 2016. "Intergroup Behavioral Strategies as Contextually Determined: Experimental Evidence from Israel." The Journal of Politics 78(3):851-867.

Finan, Frederico and Laura Schechter. 2012. "Vote buying and reciprocity." Econometrica 80(2):863-881.

Fox, Jonathan. 2008. A world survey of religion and the state. Cambridge University Press.

Freston, Paul. 2008. Evangelical Christianity and Democracy in Latin America. Oxford University Press. 
Gerber, Alan S., Jonathan Gruber and Daniel M. Hungerman. 2016. "Does Church Attendance Cause People to Vote? Using Blue Laws' Repeal to Estimate the Effect of Religiosity on Voter Turnout." British Journal of Political Science 46(03):481-500.

Grewal, Sharan, Amaney A Jamal, Tarek Masoud and Elizabeth R Nugent. 2019. "Poverty and divine rewards: The electoral advantage of Islamist political parties." American Journal of Political Science 63(4):859-874.

Grzymala-Busse, Anna. 2012. "Why Comparative Politics Should Take Religion (More) Seriously." Annual Review of Political Science 15(1):421-442.

Harrigan, Jane and Hamed El-Said. 2009. Economic Liberalisation, Social Capital and Islamic Welfare Provision. Palgrave Macmillan UK.

Hasson, Nir. 2013. “Ultra-Orthodox Jews shun Jerusalem's supposedly 'modest' shopping mall." Haaretz. June 24. Accessed September 5, 2018. https://www.haaretz.com/.premiumharedim-shun-modest-j-lem-mall-1.5285167.

Heilman, Samuel C. 1996. "The Vision from the Madrasa and Bes Medrash: Some Parallels between Islam and Judaism." Bulletin of the American Academy of Arts and Sciences $49(4): 6-37$.

Hicken, Allen. 2011. "Clientelism." Annual Review of Political Science 14:289-310.

Hopkins, Daniel J. 2010. "Politicized Places: Explaining Where and When Immigrants Provoke Local Opposition." American Political Science Review 104(01):40-60.

Iannaccone, Laurence R. 1998. "Introduction to the Economics of Religion." Journal of economic literature 36(3):1465-1495.

Iyer, Sriya. 2016. "The New Economics of Religion." Journal of Economic Literature $54(2): 395-441$. 
Kalyvas, Stathis N. 1996. The rise of Christian Democracy in Europe. Cornell University Press.

Kitschelt, Herbert and Steven Wilkinson. 2007. Patrons, clients and policies: Patterns of democratic accountability and political competition. Cambridge University Press.

Liebman, Charles S. 1993. Jewish Fundamentalism and the Israeli Polity. In Fundamentalisms and the State, ed. Martin E. Marty and R. Scott Appleby. University of Chicago Press chapter 5, pp. 68-87.

Margolis, Michele F. 2018. "How far does social group influence reach? Identities, elites, and immigration attitudes." The Journal of Politics 80(3):782-795.

McClendon, Gwyneth and Rachel Beatty Riedl. 2015. "Religion as a Stimulant of Political Participation: Experimental Evidence from Nairobi, Kenya." The Journal of Politics $77(4): 1045-1057$.

Peled, Yoav and Horit Herman Peled. 2018. The Religionization of Israeli Society. Taylor \& Francis.

Saiz, Albert and Susan Wachter. 2011. "Immigration and the neighborhood." American Economic Journal: Economic Policy 3(2):169-188.

Schelling, Thomas C. 1971. "Dynamic models of segregation." The Journal of Mathematical Sociology 1(2):143-186.

Schlozman, Daniel. 2015. When movements anchor parties: Electoral Alignments in American history. Princeton University Press.

Scott, JC. 1972. "Patron-client politics and political change in Southeast Asia." American Political Science Review 66(1):91-113. 
Sharon, Jeremy. 2013. "No solution for Jerusalem haredi kindergarten without a home - Jewish World - Jerusalem Post." Jerusalem Post. September 10. Accessed September 5, 2018. https://www.jpost.com/Jewish-World/Jewish-News/Temporary-premises-forharedi-kindergarten-in-Jerusalem-inappropriate-325758.

Shetreet, Shimon. 1999. "State and Religion: Funding of Religious Institutions-The Case of Israel in Comparative Perspective." Notre Dame Journal of Law, Ethics 8 Public Policy 13:421.

Smidt, Corwin. 2003. Religion as Social Capital: Producing the Common Good. Baylor University Press.

Smith, Amy Erica. 2019. Religion and brazilian democracy: mobilizing the people of God. Cambridge University Press.

Stokes, Susan C. 2007. Political Clientelism. In The Oxford Handbook of Political Science, ed. Robert E. Goodin. Oxford University Press chapter 31, pp. 648-674.

Stokes, Susan C., Thad Dunning, Marcelo Nazareno and Valeria Brusco. 2013. Brokers, voters, and clientelism: The puzzle of distributive politics. Cambridge University Press.

Wald, Kenneth D., Adam L. Silverman and Kevin S. Fridy. 2005. "Making Sense of Religion in Political Life." Annual Review of Political Science 8(1):121-143.

Warner, Carolyn M. 2000. Confessions of an interest group: the Catholic Church and political parties in Europe. Princeton University Press.

Whitehead, Andrew L and Samuel L Perry. 2020. Taking America Back for God: Christian Nationalism in the United States. Oxford University Press.

Willis, Aaron P. 1995. Shas - the Sephardic Torah Guardians: Religious Movement and 
Political Power. In The Elections in Israel - 1992, ed. Asher Arian and Michal Shamir. SUNY Press chapter 5, pp. 121-139.

Woolfalk, Miya. 2013. Essays on Social Contexts and Individual Politics: The Political Influence of Religious Institutions and Ethno-Racial Neighborhood Contexts PhD thesis Harvard University. 